\title{
PENDAPATAN DAN BIAYA POKOK PRODUKSI PADI DI DAERAH ALIRAN SUNGAI (DAS) WAY SEPUTIH PROVINSI LAMPUNG
}

\author{
(Revenue and Standard Cost of Rice Farming in Way Seputih Watershed Lampung Province)
}

Martsilia Amartasari, Agus Hudoyo, Achdiansyah Sulaiman

Jurusan Agribisnis, Fakultas Pertanian, Universitas Lampung, Jl. Prof. Dr. Soemantri Brojonegoro No.1

Bandar Lampung 35145, e-mail: agus.hudoyo@fp.unila.ac.id

\begin{abstract}
The objectives of this study are to analyze the revenue and the standard cost of the rice farm in Way Seputih Watershed, the Province of Lampung. The respondents were randomly chosen. The data of the rice farm were collected by interviewing rice farmers respondents in the Rainy Season (RS) 2016/2017 and the Dry Season (DS) 2017. Data were analyzed by using the economic and financial analysis. The average productivities were 5.90 ton/ha in RS 2016/2017 and 5.93 ton/ha in DS 2017. The average net revenues over the cash cost were IDR18.63 million/ha in RS 2016/2017 and IDR18.64 million/ha in DS 2017. The average net revenues over the total cost were IDR12.05 million/ha in RS 2016/2017 and IDR12.54 million/ha in DS 2017. The average standard cost for producing rice was $I D R 4,970 / \mathrm{kg}$ and its $95 \%$ confidence interval was IDR3,821/kg - IDR6,119/kg paddy.
\end{abstract}

Key words: confidence interval, revenue, rice farm, standard cost

\section{PENDAHULUAN}

Padi merupakan tanaman pangan utama di Indonesia. Produk olahan padi adalah beras yang merupakan makanan pokok untuk sebagian besar masyarakat Indonesia. Berdasarkan data dari FAO (2017), pada 2016 jumlah beras untuk pangan di Indonesia sebesar 35,20 juta ton, pakan sebesar 1,80 juta ton, bahan baku industri sebesar 7,91 juta ton, benih (setara beras) sebesar 0,42 juta ton dan tercecer sebesar 3,85 juta ton. Oleh sebab itu, kebutuhan beras ditambah tercecer adalah sebesar 49,18 juta ton. Sementara itu, produksi beras sebesar 46,98 juta ton. Hal ini berarti produksi beras lebih kecil dari kebutuhan beras dan tercecer, yakni selisihnya sebesar 3,85 juta ton.

Defisit antara produksi dan kebutuhan tersebut menunjukkan bahwa Indonesia belum berswasembada beras. Upaya peningkatan produksi, baik melalui intensifikasi maupun ekstensifikasi perlu ditingkatkan. Intensifikasi usahatani padi bertujuan untuk meningkatkan produktivitas. Oleh sebab itu, petani sebagai produsen padi berperan sangat penting dalam peningkatan produktivitas.

Peningkatan produktivitas merupakan salah satu usaha untuk meningkatkan pendapatan petani. Tidak hanya peningkatan produktivitas, pendapatan petani juga dipengaruhi oleh biaya pokok atau biaya per satuan output. Harga jual yang ditetapkan tidak boleh terlalu tinggi atau terlalu rendah karena akan merugikan produsen. Hal ini, pemerintah telah menetapkan kebijakan harga jual yang diatur dalam Peraturan Menteri Perdagangan Republik Indonesia Nomor 27/MDAG/PER/5/2017 tentang Penetapan Harga Acuan Pembelian di Petani dan Harga Acuan Penjualan di Konsumen agar tidak merugikan, baik petani maupun konsumen (Kementerian Pertanian 2017).

Berbagai penelitian mengenai analisis pendapatan usahatani padi sejauh ini sudah dilakukan oleh peneliti-peneliti terdahulu, diantaranya yaitu Romadhon (2014) menghasilkan kesimpulan bahwa rata-rata pendapatan usahatani yang diperoleh menguntungkan dan layak untuk dijalankan, Ivan's, Zakaria dan Yanfika (2013) menghasilkan kesimpulan bahwa rata-rata produktivitas dan pendapatan usahatani yang diperoleh sebesar 1,9 ton/ha dan Rp3.387.325,89 dan Prasetio (2018) menghasilkan kesimpulan bahwa pendapatan berkontribusi sebesar 70,81 persen terhadap total pendapatan rumah tangga. Sementara itu, penelitian mengenai analisis harga pokok produksi usahatani padi sudah dilakukan di antaranya yaitu Mayasari (2011) menghasilkan kesimpulan bahwa ada perbedaan harga pokok produksi dengan luas lahan, Mandei, Katiandagho, Ngangi dan Iskandar (2011) menghasilkan kesimpulan bahwa rata-rata harga pokok adalah Rp4.961,56/kg dan Zuhairoh (2015) menghasilkan 
kesimpulan bahwa rata-rata harga pokok beras adalah sebesar Rp3.005/kg.

Provinsi Lampung merupakan salah satu sentra produksi padi di Indonesia. Berdasarkan Badan Pusat Statistik Provinsi Lampung (2016), produksi padi mencapai 3,50 juta ton. Produksi padi terbesar terdapat di Kabupaten Lampung Tengah. Produksi padi di Kabupaten Lampung Tengah mencapai 0,78 juta ton. Kecamatan Seputih Raman merupakan kecamatan yang dipilih sebagai daerah penelitian di Kabupaten Lampung Tengah, dengan pertimbangan bahwa daerah ini merupakan sentra komoditas padi dan termasuk salah satu daerah aliran sungai (DAS) Way Seputih. Sebagian besar petani di Kecamatan Seputih Raman adalah petani padi sawah irigasi (BPS 2016). Berdasarkan latar belakang tersebut, penelitian ini bertujuan untuk mengetahui pendapatan dan biaya pokok usahatani padi.

\section{METODE PENELITIAN}

Penelitian ini dilaksanakan di Daerah Aliran Sungai (DAS) Way Seputih. DAS ini dipilih karena merupakan DAS terluas penghasil tanaman padi di Kabupaten Lampung Tengah. Desa-desa yang dipilih yaitu Rejo Basuki, Rama Indera, dan Buyut Baru. Waktu pelaksanaan penelitian dilakukan pada Januari - Maret 2018. Responden dalam penelitian ini adalah petani padi dengan jumlah 45 orang yang dipilih dari 309 orang Desa Rejo Basuki, Rama Indera dan Buyut Baru dengan menggunakan metode acak sederhana.

Jenis data yang digunakan dalam penelitian ini yaitu data primer. Data ini diperoleh dengan mewawancarai langsung petani menggunakan kuisioner. Jenis data yang dikumpulkan yaitu analisis usahatani padi, seperti produksi padi, luas lahan, jumlah pupuk, jumlah pestisida, dan penyusutan alat. Berikut adalah metode analisis data yang digunakan dalam penelitian ini:

Pendapatan atas biaya tunai

$=$ Penerimaan - biaya tunai

Pendapatan atas biaya total

$=$ Penerimaan - biaya total .

Keterangan:

Penerimaan $(\mathrm{Rp})=$ Produksi $(\mathrm{kg}) \mathrm{x}$ harga $(\mathrm{Rp} / \mathrm{kg})$

Biaya tunai $(\mathrm{Rp})=$ Biaya tunai yang dikeluarkan

Biaya diperhitungkan $(\mathrm{Rp})=$ Biaya tidak tunai yang dikeluarkan
Biaya total $(\mathrm{Rp})=$ Biaya tunai + biaya yang diperhitungkan

Secara matematis perhitungan biaya pokok adalah sebagai berikut:

$\mathrm{BP}=\frac{\mathrm{TC}}{\mathrm{Y}}$

Keterangan:

$\mathrm{BP}=$ Biaya pokok $(\mathrm{Rp} / \mathrm{kg})$

$\mathrm{TC}=$ Total cost $(\mathrm{Rp} / \mathrm{kg})$

$\mathrm{Y}=$ Produksi $(\mathrm{Rp} / \mathrm{kg})$

Setelah diperoleh biaya pokok untuk tiap responden, kemudian dihitung rata-rata biaya pokok dengan rumus sebagai berikut:

$\mathrm{BP}=\frac{\sum_{\mathrm{i}=1}^{\mathrm{n}} \mathrm{BPi}}{\mathrm{n}}$

Keterangan:

$\mathrm{BP}=$ Rata-rata biaya pokok $(\mathrm{Rp} / \mathrm{kg})$

$\mathrm{BP}_{\mathrm{i}}=$ Biaya pokok untuk responden ke-i $(\mathrm{Rp} / \mathrm{kg})$

$\mathrm{n}$ = Jumlah responden

Rata-rata biaya pokok yang telah didapat kemudian dilakukan perhitungan selang kepercayaan dengan menggunakan tingkat kepercayaan sebesar 95 persen $(\alpha=5 \%)$. Perhitungan selang kepercayaan biaya pokok dapat dilihat sebagai berikut (Walpole 1995):

$\mathrm{BP}-t_{\alpha / 2} \frac{s}{\sqrt{n}}<\overline{B P}<\overline{B P}+t_{\alpha / 2} \frac{s}{\sqrt{n}}$

Keterangan :

$\mathrm{BP}=$ Rata-rata biaya pokok $(\mathrm{Rp} / \mathrm{kg})$

$\mathrm{s} \quad=$ Simpangan baku $(\mathrm{Rp} / \mathrm{kg})$

$\alpha=$ Taraf nyata $5 \%$

$\mathrm{n}=$ Jumlah responden

\section{HASIL DAN PEMBAHASAN}

\section{Karakteristik Petani Responden}

Usia petani padi yaitu 45 tahun dengan kisaran usia 32-71 tahun. Tingkat pendidikan sebagian besar petani responden adalah SMP, yakni sebanyak 24 orang dengan persentase sebesar 53\%. Petani padi yang memiliki pekerjaan sampingan hanya delapan orang, yakni sebanyak 18\%. Sisanya (82\%) merupakan petani padi. Hal ini menunjukkan bahwa usahatani padi merupakan sumber pendapatan rumah tangga utama. Jumlah 
tanggungan keluarga petani berkisar antara 2-6 orang. Sebagian besar petani responden memiliki pengalaman berusahatani antara 21-30 tahun.

\section{Penggunaan Input dan Biaya}

Rata-rata luas lahan untuk usahatani padi adalah 0,82 ha. Status penguasaan lahannya adalah milik sendiri. Rata-rata input, output, biaya dan pendapatan usahatani padi per hektar dapat dilihat pada Tabel 1 untuk Musim Hujan (MH) 2016/2017 dan Tabel 2 untuk Musim Kemarau (MK) 2017.

Penggunaan benih padi ditampilkan dalam Tabel 1 dan 2 pada MH 2016/2017 dan MK 2017 adalah sebesar 24,40 kg/ha dan 25,16 kg/ha. Pada penelitian Prasetio (2018), benih yang digunakan adalah $18,36 \mathrm{~kg} / \mathrm{ha}$ dan $18,13 \mathrm{~kg} / \mathrm{ha}$. Berdasarkan anjuran dari BPTP (2018), penggunaan benih padi yaitu $25 \mathrm{~kg} / \mathrm{ha}$. Dengan demikian penggunaan pupuk di Seputih Raman sudah sesuai anjuran.

Petani padi di Kecamatan Seputih Raman menggunakan benih dengan varietas Ciherang, Serimbu, Melati, dan hibrida Aresco. Setiap benih memiliki keunggulan dan kelemahannya masingmasing. Sebagai contoh varietas Ciherang, Melati dan Serimbu, walaupun harganya murah, namun produktivitasnya lebih rendah dari varietas hibrida. Sedangkan varietas hibrida Aresco memiliki keunggulan dari aspek produktivitas dibandingkan varietas nonhibrida.

Tabel 1. Rata-rata input, output, biaya dan pendapatan usahatani padi per hektar pada MH 2016/2017

\begin{tabular}{|c|c|c|c|c|c|c|c|c|c|}
\hline \multirow{2}{*}{ No. } & \multirow{2}{*}{ Uraian } & \multirow{2}{*}{ Satuan } & \multicolumn{3}{|c|}{ Fisik } & \multirow{2}{*}{$\begin{array}{c}\text { Harga } \\
\text { (Rp/sat) }\end{array}$} & \multicolumn{3}{|c|}{ Nilai (Rp) } \\
\hline & & & DK & LK & Jumlah & & Diperhitungkan & Tunai & Total \\
\hline \multicolumn{10}{|c|}{ 1. Biaya input } \\
\hline & Benih & $\mathrm{Kg}$ & 6,49 & 17,90 & 24,40 & 19.964 & 129.575 & 357.439 & 487.014 \\
\hline & Pupuk N & $\mathrm{Kg}$ & & 248,34 & 248,34 & 1.793 & & 445.358 & 445.358 \\
\hline & Pupuk P & $\mathrm{Kg}$ & & 212,95 & 212,95 & 2.332 & & 496.549 & 496.549 \\
\hline & Pupuk K & $\mathrm{Kg}$ & & 96,05 & 96,05 & 5.181 & & 497.651 & 497.651 \\
\hline & Pupuk Majemuk & $\mathrm{Kg}$ & & 224,71 & 224,71 & 2.541 & & 570.986 & 570.986 \\
\hline & Pupuk Kandang & $\mathrm{Kg}$ & & 737,31 & 737,31 & 900 & & 663.579 & 663.579 \\
\hline & Herbisida & $\mathrm{Kg}$ & & 0,05 & 0,05 & 245.000 & & 13.259 & 13.259 \\
\hline & Fungisida & $\mathrm{Kg}$ & & 0,30 & 0,30 & 178.400 & & 53.297 & 53.297 \\
\hline & Moluskisida & $\mathrm{Kg}$ & & 0,17 & 0,17 & 750.000 & & 125.973 & 125.973 \\
\hline & Insektisida & $\mathrm{Kg}$ & & 4,21 & 4,21 & 284.853 & & 1.199 .119 & 1.199.119 \\
\hline \multicolumn{10}{|c|}{ 2. Tenaga Kerja } \\
\hline & Persemaian & HOK & 2,77 & 0,49 & 3,27 & 70.000 & 194.149 & 34.599 & 228.748 \\
\hline \multicolumn{10}{|c|}{ Pengolahan Tanah } \\
\hline & Orang & $\mathrm{HOK}$ & 5,92 & 6,16 & 12,09 & 70.000 & 414.525 & 431.481 & 846.006 \\
\hline & Mesin & Jam & & 8,00 & 8,00 & * & & 1.185 .372 & 1.185.372 \\
\hline & Cabut Benih & HOK & 1,64 & 0,08 & 1,72 & 70.000 & 114.800 & 5.613 & 120.413 \\
\hline & Garis dan Banjar & HOK & 0,95 & 0,05 & 1,00 & 70.000 & 66.449 & 3.215 & 69.664 \\
\hline & Penanaman & HOK & 1,85 & 11,48 & 13,33 & 70.000 & 129.671 & 803.280 & 932.951 \\
\hline & Penyulaman & HOK & 1,86 & 0,11 & 1,97 & 70.000 & 130.119 & 8.002 & 138.121 \\
\hline & Peny iangan & HOK & 2,17 & 0,32 & 2,49 & 70.000 & 151.566 & 22.633 & 174.199 \\
\hline & Pemupukan 1 & HOK & 1,35 & & 1,35 & 70.000 & 94.598 & & 94.598 \\
\hline & Pemupukan 2 & HOK & 1,35 & & 1,35 & 70.000 & 94.598 & & 94.598 \\
\hline & Pengendalian HPT & HOK & 4,13 & 0,95 & 5,08 & 70.000 & 288.891 & 66.742 & 355.634 \\
\hline \multicolumn{10}{|c|}{ Panen } \\
\hline & Orang & HOK & 2,99 & 42,69 & 45,69 & 70.000 & 209.476 & 2.988 .576 & 3.198.052 \\
\hline & Mesin & Jam & & 8,00 & 8,00 & $*$ & & 1.464 .444 & 1.464.444 \\
\hline \multicolumn{10}{|c|}{ 3. Biaya lain-lain } \\
\hline & Peny usutan & $\mathrm{Rp}$ & & & & & 38.541 & & 38.541 \\
\hline & Sewa Lahan & $\mathrm{Rp}$ & & & & & 3.618 .667 & & 3.618 .667 \\
\hline & Pajak & $\mathrm{Rp}$ & & & & & & 218.678 & 218.678 \\
\hline & Bunga Modal & $\mathrm{Rp}$ & & & & & 908.396 & & 908.396 \\
\hline & Biaya & $\mathbf{R p}$ & & & & & 6.584 .022 & 11.860 .899 & 18.444.921 \\
\hline \multicolumn{10}{|c|}{ 5. Penerimaan } \\
\hline & Produksi & $\mathrm{Kg}$ & & & 5.901 & 5.133 & & & 30.292 .466 \\
\hline 6. 1 & Pendapatan atas Biaya Tunai & $\mathbf{R p}$ & & & & & & & 18.431.567 \\
\hline 7. 1 & Pendapatan atas Biaya Total & $\mathbf{R p}$ & & & & & & & 11.847.545 \\
\hline
\end{tabular}

Sumber: Data primer 2018 diolah 
Tabel 2. Rata-rata input, output, biaya dan pendapatan usahatani padi per hektar pada MK 2017

\begin{tabular}{|c|c|c|c|c|c|c|c|c|c|}
\hline \multirow{2}{*}{ No. } & \multirow{2}{*}{ Uraian } & \multirow{2}{*}{ Satuan } & \multicolumn{3}{|c|}{ Fisik } & \multirow{2}{*}{$\begin{array}{c}\text { Harga } \\
\text { (Rp/sat) }\end{array}$} & \multicolumn{3}{|c|}{ Nilai (Rp) } \\
\hline & & & DK & LK & Jumlah & & Diperhitungkan & Tunai & Total \\
\hline \multicolumn{10}{|c|}{ 1. Biaya input } \\
\hline & Benih & $\mathrm{Kg}$ & 8,85 & 16,31 & 25,16 & 21.656 & 191.575 & 353.300 & 544.876 \\
\hline & Pupuk N & $\mathrm{Kg}$ & & 247,52 & 247,52 & 1.801 & & 445.815 & 445.815 \\
\hline & Pupuk P & $\mathrm{Kg}$ & & 216,95 & 216,95 & 2.316 & & 502.349 & 502.349 \\
\hline & Pupuk K & $\mathrm{Kg}$ & & 90,34 & 90,34 & 5.185 & & 468.355 & 468.355 \\
\hline & Pupuk Majemuk & $\mathrm{Kg}$ & & 223,60 & 223,60 & 2.541 & & 568.163 & 568.163 \\
\hline & Pupuk Kandang & $\mathrm{Kg}$ & & 539,26 & 539,26 & 900 & & 485.333 & 485.333 \\
\hline & Herbisida & $\mathrm{Kg}$ & & 0,05 & 0,05 & 247.692 & & 12.671 & 12.671 \\
\hline & Fungisida & $\mathrm{Kg}$ & & 0,10 & 0,10 & 176.667 & & 16.958 & 16.958 \\
\hline & Moluskisida & $\mathrm{Kg}$ & & 0,18 & 0,18 & 750.000 & & 131.528 & 131.528 \\
\hline & Insektisida & $\mathrm{Kg}$ & & 3,41 & 3,41 & 189.714 & & 646.546 & 646.546 \\
\hline \multicolumn{10}{|c|}{ 2. Tenaga Kerja } \\
\hline & Persemaian & HOK & 2,00 & 0,42 & 2,42 & 70.000 & 139.971 & 29.588 & 169.559 \\
\hline \multicolumn{10}{|c|}{ Pengolahan Tanah } \\
\hline & Orang & HOK & 5,92 & 6,16 & 12,09 & 70.000 & 414.525 & 431.481 & 846.006 \\
\hline & Mesin & Jam & & 8,00 & 8,00 & $*$ & & 1.201 .354 & 1.201.354 \\
\hline & Cabut Benih & HOK & 1,65 & 0,08 & 1,73 & 70.000 & 115.578 & 5.613 & 121.191 \\
\hline & Garis dan Banjar & $\mathrm{HOK}$ & 0,95 & 0,98 & 1,93 & 70.000 & 66.449 & 68.548 & 134.997 \\
\hline & Penanaman & HOK & 1,85 & 11,48 & 13,33 & 70.000 & 129.671 & 803.280 & 932.951 \\
\hline & Penyulaman & $\mathrm{HOK}$ & 1,84 & 0,11 & 1,96 & 70.000 & 129.082 & 8.002 & 137.084 \\
\hline & Peny iangan & HOK & 1,88 & 0,71 & 2,60 & 70.000 & 131.796 & 49.933 & 181.729 \\
\hline & Pemupukan 1 & $\mathrm{HOK}$ & 1,35 & & 1,35 & 70.000 & 94.598 & & 94.598 \\
\hline & Pemupukan 2 & $\mathrm{HOK}$ & 1,35 & & 1,35 & 70.000 & 94.598 & & 94.598 \\
\hline & Pengendalian HPT & $\mathrm{HOK}$ & 2,02 & 0,46 & 2,48 & 70.000 & 141.298 & 31.973 & 173.271 \\
\hline \multicolumn{10}{|c|}{ Panen } \\
\hline & Orang & $\mathrm{HOK}$ & 2,99 & 41,92 & 44,91 & 70.000 & 209.476 & 2.934 .492 & 3.143.968 \\
\hline & Mesin & Jam & & 8,00 & 8,00 & $*$ & & 1.464 .444 & 1.464 .444 \\
\hline \multicolumn{10}{|c|}{ 3. Biaya lain-lain } \\
\hline & Penyusutan & $\mathrm{Rp}$ & & & & & 38.541 & & 38.541 \\
\hline & Sewa Lahan & $\mathrm{Rp}$ & & & & & 3.618 .667 & & 3.618 .667 \\
\hline & Pajak, Iuran desa dan air & $\mathrm{Rp}$ & & & & & & 218.678 & 218.678 \\
\hline & Bunga Modal & $\mathrm{Rp}$ & & & & & 887.995 & & 887.995 \\
\hline & Biaya & $\mathrm{Rp}$ & & & & & 6.403 .822 & 11.083.458 & 17.487.280 \\
\hline \multicolumn{10}{|c|}{ 5. Penerimaan } \\
\hline & Produksi & $\mathrm{Kg}$ & & & 5.926 & 5.033 & & & 29.826 .694 \\
\hline 8. & Pendapatan atas Biaya Tunai & $\mathrm{Rp}$ & & & & & & & 18.743.235 \\
\hline 9. & Pendapatan atas Biaya Total & $\mathrm{Rp}$ & & & & & & & 12.339.414 \\
\hline
\end{tabular}

Pemupukan dilakukan untuk meningkatkan kesuburan tanah dan produksi. Pupuk yang biasa digunakan oleh petani padi berupa pupuk organik (kandang) dan pupuk anorganik, yaitu pupuk urea dengan bahan aktif nitrogen (N), SP-36 dengan bahan aktif fosfor (P2O), $\mathrm{KCl}$ dengan bahan aktif kalium (K) dan pupuk majemuk yaitu phonska. Pupuk unsur $\mathrm{N}$ diberikan pada saat fase vegetatif untuk mempercepat pertumbuhan tunas dan batang. Pada saat fase generatif pupuk yang diberikan adalah pupuk yang mengandung unsur fosfor (P2O) untuk merangsang pertumbuhan bunga, benih dan tanaman muda, dan pupuk yang mengandung unsur Kalium (K) untuk membantu pembentukan protein dan karbohidrat pada perkembangan buah. Kalium pun berperan dalam memperkuat tanaman dalam menghadapi kekeringan dan penyakit (BPTP Sulut 2015).
Penggunaan pestisida bertujuan untuk mengendalikan hama dan penyakit tanaman. Pestisida yang digunakan dalam usahatani padi yaitu herbisida dengan merek dagang Ally Plus untuk mengendalikan gulma, fungisida dengan merek dagang Antracol untuk mengendalikan penyakit hawar daun dan hama blast, moluskisida dengan merek dagang Bestnoid untuk mengendalikan keong, dan insektisida dengan merek dagang Lannate, Furadan, Virtako dan Metindo untuk mengendalikan wereng, sundep dan kutu kebul.

Penggunaan tenaga kerja usahatani padi terdiri dari TKDK dan TKLK yang meliputi berbagai kegiatan di antaranya persemaian, pengolahan lahan, penanaman, penyulaman, penyiangan, pemupukan 1 dan 2, pengendalian HPT dan panen. Tabel 1 
dan 2 menunjukkan bahwa penggunaan tenaga kerja yang paling banyak adalah untuk kegiatan panen, yaitu sebanyak 45,30 HOK/ha. Kegiatan pengolahan tanah dilakukan dengan menggunakan traktor dengan sistem pembayaran borongan. Rata-rata upah borongannya adalah Rp1.185.372/ha.

Rata-rata biaya tunai yang dikeluarkan oleh petani pada MH 2016/2017 dan MK 2017 secara berturutturut adalah sebesar Rp11,65 juta/ha dan Rp10,87 juta/ha. Biaya diperhitungkan sebesar Rp6,58 juta/ha untuk MH 2016/17 dan Rp6,40 juta/ha untuk MK2017. Biaya total sebesar Rp18,23 juta/ha untuk MH 2016/2017 dan Rp17,28 juta/ha.

\section{Produksi, Penerimaan dan Pendapatan}

Produksi padi pada MH 2016/2017 dan MK 2017 secara berturut-turut yaitu sebesar 5,90 ton/ha GKP dan 5,93 ton/ha GKP. Rata-rata produktivitas padi di Kecamatan Seputih Raman yaitu sebesar 6,53 ton/ha GKP atau sebesar 5,55 ton/ha GKG. Harga jual di tingkat petani berkisar antara Rp4.900/kg sampai Rp5.300/kg GKP. Oleh karena itu, penerimaan usahatani padi pada MH 2016/2017 dan MK 2017 berturut-turut sebesar Rp30,29 juta/ha dan Rp29,82 juta/ha.

Berdasarkan data pada Tabel 1 dan Tabel 2 pendapatan atas biaya tunai pada MH 2016/2017 dan MK 2017 secara berturut-turut sebesar Rp18,63 juta/ha dan Rp18,64 juta/ha. Sementara itu, rata-rata pendapatan atas biaya total sebesar Rp12,05 juta/ha untuk MH 2016/2017 dan Rp12,54 juta/ha untuk MK 2017.

\section{Biaya Pokok Produksi Padi}

Biaya pokok produksi padi yaitu total seluruh biaya produksi dibagi dengan jumlah produksi padi. Biaya produksi padi meliputi biaya benih, pupuk, pestisida, tenaga kerja, penyusutan alat, sewa lahan, pajak, iuran desa dan air, dan bunga modal. Biaya pokok dirata-ratakan untuk dua musim tanam, MH 2016/2017 dan MK 2017. Rata-rata biaya pokok produksi padi dapat dilihat pada Tabel 3.

Tabel 3 menunjukkan bahwa rata-rata biaya pokok adalah sebesar Rp4.970/kg. Biaya tertinggi adalah biaya tenaga kerja yaitu sebesar Rp2.460 (49 persen). Biaya tertinggi kedua setelah biaya tenaga kerja adalah biaya sewa lahan yaitu sebesar Rp1.012 (20 persen). Biaya sewa lahan termasuk biaya diperhitungkan.
Tabel 3. Biaya pokok produksi padi di Kecamatan Seputih Raman

\begin{tabular}{lrr}
\hline Uraian & \multicolumn{1}{l}{$\begin{array}{l}\text { Nilai } \\
(\mathbf{R p} / \mathbf{K g})\end{array}$} & \multicolumn{1}{c}{$\begin{array}{c}\text { Persentase } \\
(\%)\end{array}$} \\
\hline Biaya & 144 & 3 \\
Benih & 719 & 14 \\
Pupuk & 307 & 6 \\
Pestisida & 2.460 & 49 \\
Tenaga Kerja & 11 & 0 \\
Penyusutan Alat & 1.012 & 20 \\
Sewa Lahan & 66 & 1 \\
Pajak, Iuran desa dan air & 251 & 5 \\
Bunga Modal & 4.970 & 100 \\
Total (Biaya Pokok) & & \\
Selang Kepercayaan 95\% & 3.821 & \\
Batas bawah & 6.119 & \\
Batas atas & 3.700 & \\
\hline Harga Acuan Pemerintah & &
\end{tabular}

Selang kepercayaan 95 persen biaya pokok yaitu antara Rp3.821/kg sampai Rp6.119/kg padi. Biaya acuan untuk padi yang telah ditetapkan pemerintah yaitu Rp3.700/kg GKP (Peraturan Menteri Perdagangan Republik Indonesia Nomor 27/MDAG/PER/5/2017). Biaya acuan itu masih jauh di bawah batas tertinggi biaya pokok. Berdasarkan hal tersebut, agar petani tidak mengalami kerugian, sebaiknya penetapan harga padi dibatas tertinggi selang kepercayaan. Oleh karena itu, biaya acuan disarankan sebesar Rp6.119/kg GKP.

\section{KESIMPULAN}

Rata-rata produktivitas usahatani padi sebesar 5,90 ton/ha GKP untuk MH 2016/2017 dan sebesar 5,93 ton/ha GKP untuk MK 2017. Pendapatan atas biaya tunai usahatani padi secara berturut-turut pada musim hujan $(\mathrm{MH})$ dan musim kemarau (MK) adalah sebesar Rp18,63 juta/ha dan Rp18,64 juta/ha. Selain itu, pendapatan atas biaya total yaitu sebesar Rp12,05 juta/ha untuk MH 2016/2017 dan Rp12,54 juta/ha untuk MK 2017. Rata-rata biaya pokok usahatani padi yaitu sebesar Rp4.970/kg dengan selang kepercayaan 95 persen antara Rp3.821/kg dan Rp6.119/kg GKP.

\section{DAFTAR PUSTAKA}

BPS [Badan Pusat Statistik] Kabupaten Lampung Tengah. 2016. Lampung Tengah Dalam Angka. Badan Pusat Statistik. Gunung Sugih.

BPTP [Balai Pengkajian Teknologi Pertanian] Provinsi Sulawesi Utara. 2015. Anjuran Penggunaan Pupuk pada Tanaman Padi. 
http://sulut.litbang.pertanian.go.id/ind/index. php?option=com_content \&view $=$ article \&id $=582 \&$ Itemid $=65$ [27 Agustus 2019].

BPTP [Balai Pengkajian Teknologi Pertanian]. 2018. Anjuran Penggunaan Benih Padi. www.lampung.litbang.pertanian.go.id [27 Januari 2019].

FAO [Food and Agriculture Organization]. 2017. www.fao.org/faostat/en/\#data/fbs Januari 2019].

Handayani SA, Effendi I, Viantimala B. 2017. Produksi dan pendapatan usahatani padi di Desa Pujo Asri Kecamatan Trimurjo Kabupaten Lampung Tengah. JIIA, 5(4):422-429. http://jurnal.fp.unila.ac.id/index.php/JIA/arti cle/view/1752/1555 [7 Oktober 2019]

Ivan's E, Zakaria WA, Yanfika H. 2013. Analisis Produksi dan pendapatan usahatani padi sawah di Kecamatan Perbolinggo Kabupaten Lampung Timur. JIIA, 1(3):238-245. http://jurnal.fp.unila.ac.id/index.php/JIA/arti cle/view/579/541 [16 Februari 2019]

Kementerian Pertanian. 2017. Outlook Tanaman Pangan dan Hortikultura. Pusat Data dan Sistem Informasi Pertanian. Sekretariat Jendral. Jakarta.

Mayasari A. 2011. Analisis Penentuan Harga Pokok Produksi pada Petani Padi (Studi Kasus di Desa Balong Kecamatan Kembang Kabupaten Jepara). Skripsi. Program Studi Akuntasi. Sekolah Tinggi Ilmu Ekonomi Nahdlatul Ulama (Stienu). Jepara.

Mandei JR, Katiandagho T, Ngangi CR, dan Iskandar JN. 2011. penentuan harga pokok beras di Kecamatan Kotamobagu Timur
Kota Kotamobagu. Jurnal ASE, 7(2):15-21. https://media.neliti.com/media/publications/ 3452-ID-analisis-pendapatan-usahatanibunga-potong-studi-kasus-petani-bungakrisan-putih.pdf [16 Februari 2019]

Putri MI, Ismono H, Indriani Y. 2017. Pendapatan usahatani padi yang menerapkan sistem resi gudang di Kecamatan Pulau Panggung Kabupaten Tanggamus. JIIA, 5(2):134-141. http://jurnal.fp.unila.ac.id/index.php/JIA/arti cle/view/1650/1476 [7 Oktober 2019]

Prasetio DE. 2018. Analisis Pendapatan dan Tingkat Kesejahteraan Petani Padi Sawah (Oryza Satifa) di Kabupaten Lampung Tengah. Skripsi. Fakultas Pertanian Universitas Lampung. Lampung.

Romadhon GJ. 2014. Analisis Pendapatan Usahatani dan Faktor-Faktor yang Mempengaruhi Produksi Padi Hibrida dan Inbrida (Studi Kasus: Desa Suru, Kecamatan Doko, Kabupaten Blitar, dan Desa Clumprit, Kecamatan Pagelaran, Kabupaten Malang, Jawa Timur). Skripsi. Fakultas Ekonomi dan Manajemen Institut Pertanian Bogor (IPB). Bogor.

Walpole RE. 1995. Pengantar Statistika, edisi ketiga. Penerbit PT. Gramedia Pustaka Utama. Jakarta.

Zuhairoh I. 2015. Analisis Penentuan Harga Pokok Beras dengan Menggunakan Metode Full Costing pada Usahatani Beras di Kecamatan Undaan Kabupaten Kudus pada Musim Panen Bulan Juli 2015. Skripsi. Fakultas Ekonomi dan Bisnis Universitas Dian Nuswantoro. Semarang. 